\title{
Advances in Micropropagation of a Highly Important Cassia species- A Review
}

\author{
M. Anis ${ }^{1,2^{*}}$, Iram Siddique ${ }^{3}$, Ruphi Naz ${ }^{1}$, \\ M. Rafique Ahmed ${ }^{1}$ and Ibrahim M. Aref ${ }^{2}$ \\ ${ }^{1}$ Plant Biotechnology Laboratory, Department of Botany, \\ Aligarh Muslim University, Aligarh, \\ ${ }^{2}$ Department of Plant Production, College of Food \& Agricultural Sciences, \\ King Saud University, Riyadh, \\ ${ }^{3}$ Department of Botany and Microbiology, College of Science, \\ King Saud University, Riyadh, \\ ${ }^{1}$ India \\ 2,3Saudi Arabia
}

\section{Introduction}

The medicinal properties of plant species have made an outstanding contribution in the origin and evolution of many traditional herbal therapies. Over the past few years, however, the medicinal plants have regained a wide recognition due to an escalating faith in herbal medicine in view of its lesser side effects compared to allopathic medicine in addition the necessity of meeting the requirements of medicine for an increasing human population.

With an ever increasing global inclination towards herbal medicine for healthcare and their boom in recent years has imposed a great threat to the conservation of natural resources and endangered plant species. Currently 4,000-10,000 medicinal plants are on the endangered species list and this number is expected to increase (Canter et al., 2005). Most of the pharmaceutical industry is highly dependent on wild population for the supply of raw material for extraction of medicinally important compounds. The genetic diversity of medicinal plants in the world are getting endangered at an alarming rate because of ruinous harvesting practice and over-harvesting for production of medicines, with little or no regard to the future. Also, extensive destruction of the plant-rich habitat as a result of forest degradation, agriculture encroachments, urbanization, etc. is other factors.

In modern medicine, plants are used as sources of direct therapeutic agents, as model for new synthetic compounds and as a taxonomic marker for the elaboration of more complex semisynthetic chemical compounds (Akerele, 1992). Wide variations in medicinal quality and content in phytopharmaceutical preparations have been observed. These are influenced mainly by cultivation period, season of collection, plant- to- plant variability in the medicinal content, adulterants of medicinal preparations with misidentified plant species, a lack of adequate methods for the production and standardization of the plants, a lack of

\footnotetext{
${ }^{*}$ Corresponding Author
} 
understanding of the unique plant physiology or efficacy with human consumption and consumer fraud. Generally, herbal preparations are produced from field- grown plants and are susceptible to infestation by bacteria, fungi and insects that can alter the medicinal content of the preparations (Murch et al., 2000). Also there is significant evidence to show that the supply of plants for traditional medicines is failing to satisfy the demand (Cunningham 1993). An efficient and most suited alternative solution to the problems by the phytopharmaceutical industry is development of in vitro systems for the production of medicinal plants and their extracts.

\section{Role of biotechnology}

Biotechnology involves modern tissue culture, cell biology and molecular biology offers the opportunity to develop new germplasms that are well adapted to changing demands. Biotechnological tools are also equally important for multiplication and genetic enhancement of the medicinal plants by adopting various techniques such as in vitro regeneration and genetic transformation. It can also be harnessed for the production of secondary metabolites using plant as bioreactors (Tripathi and Tripathi, 2003). In addition, modern biotechnology is being increasingly applied for plant diversity characterization and they have a major role in assisting plant conservation programmes.

\section{Plant tissue culture}

In recent years, tissue culture has emerged as a promising technique for culturing and studying the physiological behaviour of isolated plant organs, tissues, cells, protoplasts and even cell organelles under precisely controlled physical and chemical conditions. Tissue culture can be divided into three broad categories. The most common approach is to isolate organised meristems like shoot tips or axillary buds and induce them to grow into complete plants (Fig1A-F). This system of propagation is commonly referred to as micropropagation. In the second approach, adventitious shoots are initiated on leaf, root and stem segments or on callus derived from those organs. The third system of propagation involves induction of somatic embryogenesis in cell and callus cultures. The commercial technology is primarily based on micropropagation, in which rapid proliferation is achieved from tiny stem cutting, axillary buds and to a limited extent from somatic embryos, cell clumps in suspension cultures and bioreactors. This technique is being used for large scale propagation of a number of plant species viz. Rauvolfia tetraphylla (Faisal et al., 2005), Tylophora indica (Faisal and Anis, 2003), Vitex negundo (Ahmad and Anis, 2007), Pterocarpus marsupium (Husain et al., 2007), Mucuna pruriens (Faisal et al., 2006), Balanites aegyptiaca (Siddique and Anis, 2009). Although there are a number of reviews published on micropropagation of medicinal plants, they do not provide the comprehensive micropropagation reports on Cassia species. In this way, the present review highlighted in vitro regeneration of medicinally important Cassia species, their significance and the wide scope existing for investigations on mass cloning of these plants.

\subsection{Cassia angustifolia Vahl. (Fabaceae)}

Cassia angustifolia Vahl. is a small medicinal shrub commonly known as senna, a valuable drought resistant plant. It is mainly grown as a cash crop in various parts of the world (Anonymous, 1992).The leaves and pods of senna are chief source of anthraquinone, glycoside known as sennosides, which are extensively used as a laxative. It is also used as a 
febrifuge in splenic enlargements, anaemia, typhoid, cholera, biliousness, jaundice, gout, rheumatism, tumours, foul breath and bronchitis and in leprosy (Pulliah, 2002). It is employed in the treatment of amoebic dysentery as an anthelmintic and as a mild liver stimulant. Poor seeds viability and low germination frequency restricts its propagation on a large scale. Therefore, micropropagation appears to be an alternative method in order to meet the demand for commercial production of this medicinal plant.

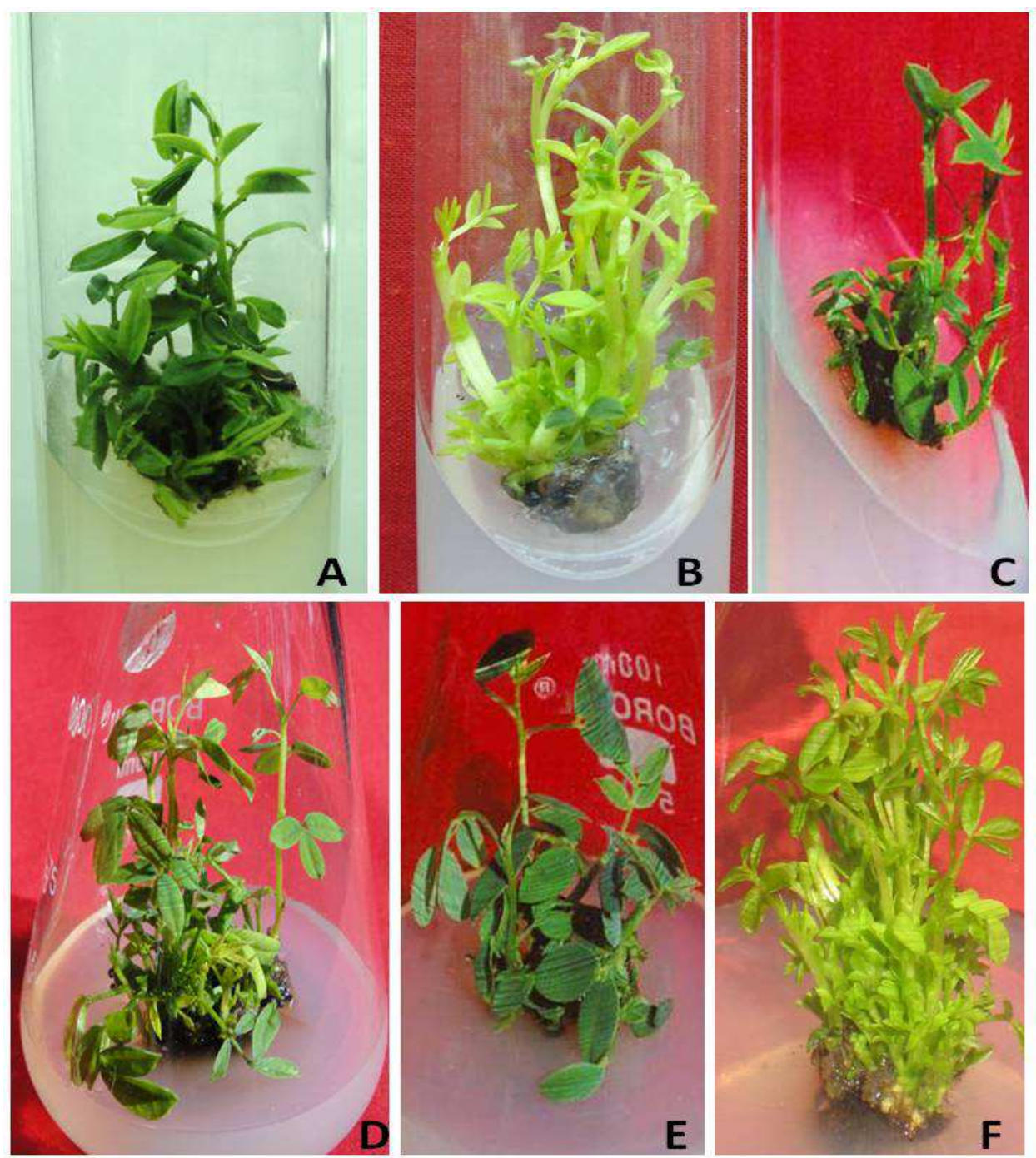

Fig. 1. (A-F). A. Shoots induction in Cassia occidentalis on MS medium containing BA. B. Shoot induction in C. alata. C. Multiple shoot induction from cotyledonary node explant of C. angustifolia D. Multiplication and elongation of shoots from cotyledonary node explant of C. occidentalis E\& F. Shoot proliferation in C. angustifolia and C. alata. 


\subsubsection{Explant type}

Multiple shoots were developed successfully from different explants (Cotyledonary node, nodal and shoot tips) excised from in vitro grown seedlings of C. angustifolia (Agrawal and Sardar 2003; Siddique and Anis 2007 a, b). Among the various explants, cotyledonary node gave the best response (Agrawal and Sardar, 2003), (Siddique and Anis, 2007a, b). In addition, plant regeneration has been successfully developed by using root explants (Parveen and Shahzad 2011). Root explants are advantageous over other explants in terms of their easy manipulation, higher regeneration potential and excellent susceptibility for Agrobacterium transformation (Knoll et al., 1997).

In the second approach a much faster rate of multiplication has been obtained through indirect organogenesis. Different explants (Cotyledons, leaflets and petiole) excised from axenic seedlings were used for inducing organogenic callus. Agrawal and Sardar (2006) used cotyledons and leaflets for in vitro propagation. Cotyledons were more responsive where $91 \%$ cultures produced about 12 shoots per explant. Siddique et al. (2010) used petiole for indirect shoot organogenesis in C. angustifolia.

\subsubsection{Growth regulators}

Plant growth regulators play an important role in growth and development (Little and Savidage, 1987). A range of auxins and cytokinins played a vital role in multiple shoot regeneration in many Cassia species. MS medium with optimal quantity of cytokinins (BA, $\mathrm{Kn}, 2-\mathrm{iP}$ or TDZ) is required for shoot proliferation in many genotypes but inclusion of low concentration of auxins along with cytokinin triggers the rate of shoot multiplication (Tsay et al., 1989). BA individually within the range of $0.5-10.0 \mu \mathrm{M}$ was common in most of the in vitro micropropagated plants. According to Agrawal and Sardar (2003) $1.0 \mu \mathrm{M}$ 6benzyladenine (BA) was found best to induce multiple shoots in $\mathrm{CN}$. However, at higher concentration of BA $(10.0 \mu \mathrm{M})$, a decreasing trend in response in terms of percentage responding explants, average shoot number per explants as well as average shoot length was seen. Also, $\mathrm{CN}$ gave the best response in MS medium fortified with $1.0 \mu \mathrm{M}$ thidiazuron (TDZ). In case of nodal explants best result was obtained with $5.0 \mu \mathrm{M}$ TDZ and $1.0 \mu \mathrm{M}$ Indole-3-acetic acid (IAA). Further, transfer of shoot clusters in hormone free MS medium considered to increase the rate of multiplication (Siddique and Anis, 2007a, b). TDZ has also been successfully used to induce shoot bud in root explants. To avoid adverse effect of TDZ, culture were transferred to shoot regeneration medium, where $2.5 \mu \mathrm{M} B A+0.6 \mu \mathrm{M}$ NAA gave the maximum response (Parveen and Shahzad, 2011).

In cotyledons and leaflets explants, multiple shoots were observed when green, morphogenic callus $(1.0 \mu \mathrm{M} 2.4-\mathrm{D}+1.0 \mu \mathrm{M}$ BA) was transferred to BA + NAA (Agrawal and Sardar 2006). In case of petiole, highest number of shoots and shoot length was recorded on MS medium along with $5.0 \mu \mathrm{M}$ TDZ and $1.5 \mu \mathrm{M}$ IAA (Siddique et al., 2010).

\subsubsection{Somatic embryogenesis}

Somatic embryogenesis is the most striking confirmation of totipotency, it is a process where groups of somatic cells/tissues lead to the formation of somatic embryos which resemble the zygotic embryos of intact seeds and grow into seedlings on suitable medium. Types of 
auxins and its interaction with cytokinins significantly influenced on somatic embryogenesis. Plant regeneration via somatic embryogenesis from single cells, that can be induced to produce an embryo and then complete plant, has been demonstrated in many plant species (Wann et al. 1987). In Cassia angustifolia, direct and indirect somatic embryos were observed on MS medium supplemented with auxin alone or in combination with cytokinins (Agrawal and Sardar, 2007). Efficient development and germination of somatic embryos are prerequisites for commercial plantlet production.

Besides this, antimutagenic and genotoxic potential of senna have been reported by Silva et al., (2007). Hence it is a commercially important medicinal plant which has diverse medicinal applications, there is pressing need to conserve the plant by in situ and ex situ multiplication in general and micropropagation.

\subsection{Cassia siamea Lam}

Cassia siamea Lam. (Caesalpiniaceae), is an evergreen tree, commonly planted as an avenue and shade tree in tea estates and found useful for afforestation of degraded and wastelands where organic manure is deficient. It decreases soil erosion, while improving soil fertility in the plantation site, well adapted to a variety of climatic conditions within the tropics and highly resistant to drought. The anthraquinones and cassiamin B present in the plant is an antitumour promoting and chemopreventing agent (Sastry et al., 2003). The root and bark is used in folklore medicine to treat stomach complaints and as a mild purgative. Therefore, a systematic propagation of this valuable tree is important.

\subsubsection{Explant type}

Various explants, shoot tip, cotyledonary node and nodal segments excised from in vitro raised seedlings were used for multiplication. Maximum response was observed with nodal segments in MS macro salts $+B_{5}$ micro salts (Sreelatha et al., 2007). In contrast, according to Parveen et al., (2010), cotyledonary node gave the best response in MS medium supplemented with BA and NAA. Gharyal and Maheshwari (1990) used stem and petiole for in vitro propagation. Gharyal et al., (1983) used C. siamea for androgenesis also.

\subsubsection{Growth regulators}

Sreelatha et al., (2007) used the different medium MS, B5 and MS macro salts + B5 micro salts with various hormones alone or in combinations. $0.1 \mathrm{mg} / 1 \mathrm{Kn}+0.1 \mathrm{mg} / 1 \mathrm{TDZ}+2.0$ $\mathrm{mg} / 1$ 2-iP gave the best response on MS macro salts + B5 microsalts in nodal explants. Parveen et al., (2010) found that MS medium augmented with $1.0 \mu \mathrm{M}$ BA + $0.5 \mu \mathrm{M}$ NAA was the best medium for multiple shoot regeneration in $\mathrm{CN}$ explants. B5 basal medium supplemented with $0.5 \mathrm{mg} / 1 \mathrm{IAA}+1 \mathrm{mg} / 1 \mathrm{BA}$ gave the best response in stem segments (Gharyal and Maheshwari 1990).

\subsection{Cassia sophera Linn}

Cassia sophera Linn (Fabaceae) is an important medicinal plant. The whole plant extracts and leaves have expectorant properties, cures cough, asthma and acute bronchitis, anticancer and anti-inflammatory properties. They are specific to eliminate ring worms and also useful 
in the treatment of gonorrhoea and syphilis. The bark is used in the treatment of diabetes; wounds and ascites (Anonymous, 1992). The root is administered internally with black pepper for snake bite. The seed extract exhibited important pharmacological effects like analgesic, hypnotic, sedative and antiepileptic effects (Bilal et al., 2005). Nature has provided us a rich store house of herbal remedies to cure most diseases. In vitro regeneration is the best alternative to overcome these hurdles. Conventionally $C$. sophera can be propagated through seeds. The seeds however remain viable for a short period and germinated poorly. Because of wide spectrum of its medicinal properties, Parveen and Shahzad (2010) has developed a protocol for rapid multiplication of this valuable plant through cotyledonary node, excised from in vitro raised seedlings.

\subsubsection{Explant types and growth regulators}

Cotyledonary node explants were cultured on Murashige and Skoog medium (MS) supplemented with thidiazuron (TDZ, $0.1-10.0 \mu \mathrm{M}$ ). $2.5 \mu \mathrm{M}$ TDZ proved to be optimal for the production of maximum number of shoots. For further multiplication and elongation, shoot clusters were transferred to various concentrations of BA. 1.0 $\mu \mathrm{M}$ BA showed better response.

\subsection{Cassia fistula Linn}

Cassia fistula Linn. (Caesalpiniaceae) commonly known as 'Indian Laburnum' has been extensively used in Ayurvedic system of medicine for various ailments. The whole plant possesses medicinal properties useful in the treatment of skin diseases, rheumatism, anorexia, jaundice, antitumour, antiseptic and antimicrobial (Kirtikar and Basu 1991) and antifungal activity (Gupta, 2010). It possesses hepatoprotective, anti-inflammatory and antioxidant activities (Ilavarasan et al., 2005). Both the leaves and pods were widely used in traditional medicine as strong purgative and laxatives (Kirtikar and Basu 1975, Elujoba et al., 1999) due to presence of sennoside (Van, 1976). In Ayurvedic medicinal system, it was used against various disorders such as pruritus, leucoderma, diabetes and other ailments (Satyavati and Sharma 1989, Alam et al.,1990, Asolkar et al.,1992). Leaves were also found effective against cough and ring worm infections (Chopra et al., 1956, Biswas and Ghose 1973). It is also used in treating bone fracture (Ekanayak 1980). Kuo et al., (2002) have isolated and identified oxyanthraquinones, chrysophenol and chrysophanein from the seeds. Extensive studies have been carried out on its medicinal values and the synergistic actions. Patel et al., (1965) reported analgesic and antipyretic action. Mazumdar et al., (1998) reported sedative and analgesic action of C. fistula seeds. Gupta and Jain (2009) have reported hypolipidemic activity of this important legume. It has also been reported for antiinflammatory (Suwal, 1993), hypoglycaemic activity (Alam et al., 1990; Esposito et al., 1991), antiperiodic (Kashiwada et al., 1990), anti rheumatic (Suwal, 1993), anti-tumor (Bodding, 1983; Gupta et al., 2000), hepato-protective (Bhakta et al., 1999), antioxidant (Luximon Ramma et al., 2002; Sidduraju et al., 2002), anti fungal and anti bacterial activities (Patel and Patel, 1956; Ramakrishna and Indragupta, 1997; Dhar and Qasba, 1984; Perumal et al., 1998).

\subsubsection{Explant type and growth regulators}

There are only few reports available for in vitro regeneration of C. fistula. Gharyal and Maheshwari (1990) used the stem and petiole for shoot regeneration. Stem and petiole were 
cultured on B5 basal medium supplemented with $2 \mathrm{mg} / 1 \mathrm{NAA}+0.5 \mathrm{mg} / 1 \mathrm{BA}$ (medium a) or $0.5 \mathrm{mg} / \mathrm{l} \mathrm{IAA}+1.0 \mathrm{mg} / 1 \mathrm{BA}$ (medium $\mathrm{b}$ ). Medium $\mathrm{b}$ gave the best response where well differentiated shoots were developed.

\subsection{Cassia obtusifolia L Syn Cassia tora}

It is also an important medicinal plant. The seeds are effective for insomnia, headache, constipation, oliguria, cough, opthalmia, dacryoliths, omblyopia and hypertension (Purohit and Vyas, 2005). The roots extract contain tannins, flovonoids, alkaloids (Olabiyi et al., 2008), betulinic acid, chrysophanol, physcion, stigmasterol and aloe-emodin (Yang et al., 2006). Doughari et al., (2008) reported that leaf extracts contain the activity against both gram positive and gram negative bacteria and fungi that can therefore be employed in the formulation of antimicrobial agents for the treatment of various bacterial and fungal infections including gonorrhea, pneumonia, eye infections and mycotic infections. Also Joshi (2000) reported that the plant extract is antiviral, spasmolytic and diuretic used against epilepsy, scabies and sores.

\subsubsection{Explants and growth regulators}

Hasan et al., (2008) used shoot tips for callus induction and shoot regeneration. Shoot tips were cultured in MS medium supplemented with different concentrations and combinations of 2,4-D and Kn. $2.0 \mathrm{mgl}^{-1} 2,4-\mathrm{D}+0.2 \mathrm{mgl}^{-1} \mathrm{Kn}$ were found best for shoot induction as well as elongation.

\subsection{Cassia occidentalis Linn}

Cassia occidentalis (Linn) (Caesalpiniaceae) commonly known as Coffee Senna. It is an ayurvedic plant with huge medicinal importance. It is used for fever, menstrual problems, tuberculosis, diuretic, anemic, liver complaints ( Kritikar and Basu 1999). This weed has been known to possess antifungal and anti-inflammatory activity. An infusion of the bark is given in diabetes (Anonymous 1998). Leaf extracts have antibacterial (Jain et al., 1998 and Saganuwan and Gulumbe 2006), antimalarial (Arya et al., 2010), antimutagenic (Tona et al., 1999 and Jafri et al., 1999), antiplasmodial (Sharma et al., 2000), anticarcinogenic (Tona et al., 2004) and hepatoprotective (Sharma et al., 2000) and analgesic and antipyretic (Sini et al., 2010) activity. A wide range of chemical compounds including achrosin, aloe-emodin, emodin, anthraquinones, anthrones, apigenin, aurantiobtusin, campesterol, cassiollin, chryso-obtusin, chrysophanic acid, chrysarobin, chrysophanol, chrysoeriol etc. have been isolated from this plant. Further, micropropagation of C. occidentalis Linn is being conducted in tissue culture laboratory of Botany department at AMU Aligarh.

\subsection{Cassia alata L.}

Cassia alata L. (Fabaceae) commonly known as Ringworm Bush is an erect medicinal shrub or small tree distributed mainly in the tropics and subtropics. The plant is a source of chrysoeriol, kaempferol, quercetin, 5,7,4'-trihydroflavanone, kaempferol-3-O- $\beta$-Dglucopyranoside, kaempferol-3-O- $\beta$-D-glucopyranosyl-(1->6)- $\beta$-D-glucopyranoside, $17-$ hydrotetratriacontane, n-dotriacontanol, n-triacontanol, palmitic acid ceryl ester, stearic 
acid, palmitic acid (Liu et al., 2009). C. alata leaf is also credited for the treatment of haemorrhoids, constipation, inguinal hernia, intestinal parasitosis, blennorrhagia, syphilis and diabetes (Abo et al., 1998; Adjanahoun et al., 1991). The flowers and leaves are used for the treatment of ringworms and eczema. The other uses of C. alata are as an antihelminthic, antibacterial, laxative, diuretic, for treatment of snakebites and uterine disorders (Kirtikar and Basu, 1975). Besides the leaf extract of this species has shown several pharmacological properties such as antimicrobial, antifungal (Khan et al., 2001), antiseptic (Esimone et al., 2008), anti-inflammatory, analgesic (Palanichamy and Nagarajan, 1990) and antihyperglycemic activities (Palanichamy et al., 1988). It contains therapeutic (Damodaran and Venkataraman, 1994) and anti-ageing activities (Pauly et al., 2002) also.

\subsubsection{Explant and growth regulators}

FettNeto et al., (2000) used cotyledonary node along with one third of the hypocotyl and cotyledons. The best result was obtained on 0.5 micro MS salts $+0.38 \mathrm{mgl}^{-1}$ of BA and 0.005

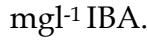

\subsection{Root development and acclimatization}

The induction of roots in vitro is an important step in plant micropropagation and genetic transformation. In vitro root induction from growing shoots has been achieved in standard media containing auxin and in media in the absence of auxin depending on plant genotype (Rout et al., 1989) (Fig. 2 A-C). There is marked variation in the rooting potential of different plant species and systematic trials are often needed to define the conditions required for root induction. Agrawal and Sardar (2006) examined the effectiveness of various auxins on rooting of $C$. angustifolia microshoots and found that $10.0 \mu \mathrm{M}$ IBA was superior to IAA or NAA. However $200 \mu \mathrm{M}$ IBA was best for ex vitro rooting in C. angustifolia (Parveen and Shahzad 2011). According to Parveen et al., (2010) $2.5 \mu \mathrm{M}$ IBA gave the maximum roots in $C$. siamea. Sreelatha et al., (2007) reported that NAA $(1.0 \mathrm{mg} / \mathrm{l})+$ IBA $(0.25 \mathrm{mg} / \mathrm{l})$ produced long and well developed roots in C. siamea. $0.1 \mathrm{mg} / 1 \mathrm{IAA}$ exhibited the positive effect on root induction in C. fistula (Gharyal and Maheshwari 1990).

Prolific rooting on in vitro grown microshoots is critical for the successful establishment of these shoots in the greenhouse or field. Plantlets were developed within the culture vessels under low level of light, aseptic conditions, on a medium containing sugar and nutrients to allow for heterotrophic growth and in an atmosphere with high level of humidity. These contribute a culture- induced phenotype that cannot survive the environmental conditions when directly placed in a greenhouse or field. The physiological and anatomical characteristics of micropropagated plantlets necessitate that they should be gradually acclimatized to the environment of the greenhouse or field (Fig 2 D, E). In C. siamea, Sreelatha et al., (2007) reported that when micropropagated plantlets were transferred to pots containing (3:1) vermiculite: sand under greenhouse conditions, about $40 \%$ of the plants survived. A high survival $85 \%$ was recorded when plantlets of C. siamea were transplanted into 1:1 sterilized garden soil and garden manure (Parveen et. al., 2010). Siddique and Anis (2007) noted the highest survival of $C$. angustifolia when the plants were maintained inside the growth room in sterile soilrite for 4 weeks and eventually transferred to natural soil. Approximately $70 \%$ of rooted plants of C. obtusifolia survived in pots containing a 1:1:1 mixture of sterile sand, soil and farmyard manure (Hasan et al., 2008). 


\begin{tabular}{|c|c|c|c|c|c|c|c|}
\hline Plant name & Explant & \begin{tabular}{|l|} 
Media/ \\
Adjuvant
\end{tabular} & $\begin{array}{l}\text { PGRs } \\
\text { used }\end{array}$ & Response & $\begin{array}{l}\text { Optimal } \\
\text { response }\end{array}$ & \begin{tabular}{|l|} 
No of \\
shoots
\end{tabular} & References \\
\hline $\begin{array}{l}\text { Cassia } \\
\text { angustifolia }\end{array}$ & $\begin{array}{l}\mathrm{CN}, \mathrm{N}, \\
\mathrm{St}\end{array}$ & MS & $\mathrm{BA}, \mathrm{Kn}$ & $\begin{array}{l}\text { Direct and } \\
\text { Indirect }\end{array}$ & $1.0 \mu \mathrm{M}$ BA & 2 & $\begin{array}{l}\text { Agrawal and } \\
\text { Sardar, (2003) }\end{array}$ \\
\hline C.angustifolia & $\mathrm{L}, \mathrm{C}$ & MS & $\begin{array}{l}\text { 2,4-D,BA, } \\
\text { Kn,NAA }\end{array}$ & Indirect & $\begin{array}{l}5.0 \mu \mathrm{M} \text { BA+ } \\
0.5 \mu \mathrm{M} \text { NAA }\end{array}$ & 12 & $\begin{array}{l}\text { Agrawal and } \\
\text { Sardar, (2006) }\end{array}$ \\
\hline C. angustifolia & $\mathrm{N}$ & MS & $\begin{array}{l}\text { BA, TDZ, } \\
\text { IAA, } \\
\text { NAA } \\
\end{array}$ & Direct & $\begin{array}{l}5.0 \mu \mathrm{M} \text { TDZ+ } \\
1.0 \mu \mathrm{M} \text { IAA }\end{array}$ & 12 & $\begin{array}{l}\text { Siddique and } \\
\text { Anis, (2007a) }\end{array}$ \\
\hline C. angustifolia & $\mathrm{CN}$ & MS & TDZ & Direct & $1.0 \mu \mathrm{M}$ TDZ & 17 & $\begin{array}{l}\text { Siddique and } \\
\text { Anis, (2007b) }\end{array}$ \\
\hline C. angustifolia & C & MS & $\begin{array}{l}\text { 2,4-D, } \\
\text { NAA } \\
\text {,BA,Kn, } \\
\text { 2-iP } \\
\text { Zeatin }\end{array}$ & $\begin{array}{l}\text { Somatic } \\
\text { embryo }\end{array}$ & $\begin{array}{l}10.0 \mu \mathrm{M} 2,4-\mathrm{D}+ \\
2.5 \mu \mathrm{M} \text { BA or } \\
5.0 \mu \mathrm{M} \text { BA }\end{array}$ & 19 & $\begin{array}{l}\text { Agrawal and } \\
\text { Sardar } \\
(2007)\end{array}$ \\
\hline C. angustiolia & $\mathrm{P}$ & MS & $\begin{array}{l}2,4- \\
\mathrm{D}, \mathrm{TDZ}, \\
\mathrm{BA}, \mathrm{Kn}\end{array}$ & Indirect & $\begin{array}{l}5.0 \mu \mathrm{M} \text { TDZ }+ \\
1.5 \mu \mathrm{M} \text { IAA }\end{array}$ & 12 & $\begin{array}{l}\text { Siddique et al., } \\
(2010)\end{array}$ \\
\hline C. angustifolia & $\mathrm{R}$ & MS & $\begin{array}{l}\text { BA, Kn, } \\
\text { TDZ } \\
\text { IAA, } \\
\text { NAA }\end{array}$ & Indirect & $\begin{array}{l}2.5 \mu \mathrm{MBA}+0.6 \\
\mu \mathrm{M} \text { NAA }\end{array}$ & 24 & $\begin{array}{l}\text { Parveen and } \\
\text { Shahzad } \\
(2011)\end{array}$ \\
\hline Cassia siamea & A & $\begin{array}{l}\text { B5/Cocon } \\
\text { ut } \\
\text { milk }\end{array}$ & $\begin{array}{l}2,4-\mathrm{D}, \\
\mathrm{Kn}\end{array}$ & Indirect & $\begin{array}{l}2 \mathrm{mg} / 12,4-\mathrm{D}, \\
0.5 \mathrm{mg} / 1 \mathrm{Kn}, \\
15 \% \\
\text { coconut milk }\end{array}$ & $\begin{array}{l}\text { Pollen } \\
\text { Embry- } \\
\text { oids }\end{array}$ & $\begin{array}{l}\text { Gharyal et al., } \\
(1983)\end{array}$ \\
\hline C. siamea & S, P & $\begin{array}{l}\text { B5/PVP, } \\
\text { PVPP }\end{array}$ & $\begin{array}{l}\text { BA,IAA, } \\
\text { NAA }\end{array}$ & Indirect & $\begin{array}{l}0.5 \mathrm{mg} / 1 \mathrm{IAA} \\
+1 \mathrm{mg} / 1 \mathrm{BA}\end{array}$ & \begin{tabular}{|l|} 
Only \\
green \\
Meriste \\
moid \\
Observed \\
\end{tabular} & $\begin{array}{l}\text { Gharyal and } \\
\text { Maheshwari } \\
(1990)\end{array}$ \\
\hline C. siamea & $\begin{array}{l}\mathrm{St}, \mathrm{CN}, \\
\mathrm{N}\end{array}$ & $\begin{array}{l}\text { MS macro } \\
\text { salt } \\
+ \text { B5 micro } \\
\text { salt }\end{array}$ & \begin{tabular}{|l|} 
BA,Kn,2- \\
iP, \\
TDZ, \\
NAA, \\
IBA, IAA
\end{tabular} & Direct & $\begin{array}{l}0.1 \mathrm{mg} / 1 \mathrm{Kn}+ \\
0.1 \mathrm{mg} / 1 \mathrm{TDZ}+ \\
2 \mathrm{mg} / 12-\mathrm{iP}\end{array}$ & 20 & $\begin{array}{l}\text { Sreelatha et al., } \\
(2007)\end{array}$ \\
\hline C. siamea & $\mathrm{CN}$ & MS & $\begin{array}{l}\mathrm{BA}, \mathrm{Kn}, \\
\mathrm{TDZ}\end{array}$ & Direct & $\begin{array}{l}1.0 \mu \mathrm{M} \text { BA } \\
+0.5 \mu \mathrm{M} \text { NAA }\end{array}$ & 12 & $\begin{array}{l}\text { Parveen et al., } \\
(2010)\end{array}$ \\
\hline Cassia sophera & $\mathrm{CN}$ & MS & $\mathrm{BA}, \mathrm{TDZ}$ & Direct & $1.0 \mu \mathrm{M} \mathrm{BA}$ & 14 & $\begin{array}{l}\text { Parveen and } \\
\text { Shahzad, (2010) }\end{array}$ \\
\hline Cassia fistula & S, P & $\begin{array}{l}\text { B5/PVP,P } \\
\text { VPP }\end{array}$ & $\begin{array}{l}\text { BA, } \\
\text { NAA, } \\
\text { IAA } \\
\end{array}$ & Indirect & $\begin{array}{l}0.5 \mathrm{mg} / 1 \mathrm{IAA} \\
1.0 \mathrm{mg} / 1 \mathrm{BA}\end{array}$ & - & $\begin{array}{l}\text { Gharyal and } \\
\text { Maheshwari } \\
(1990)\end{array}$ \\
\hline Cassia alata & $\begin{array}{l}\mathrm{CN} \\
\text { with } \\
\mathrm{H}, \mathrm{C}\end{array}$ & $\begin{array}{l}\text { MS macro } \\
+ \text { B5 } \\
\text { micro salt }\end{array}$ & $\begin{array}{l}\text { BA, } \\
\text { NAA, } \\
\text { IBA }\end{array}$ & Indirect & $\begin{array}{l}0.38 \mathrm{mg} / 1 \mathrm{BA}, \\
0.05 \mathrm{mg} / 1 \mathrm{IBA}\end{array}$ & & $\begin{array}{l}\text { Fett Neto et al., } \\
(2000)\end{array}$ \\
\hline $\begin{array}{l}\text { Cassia } \\
\text { obtusifolia }\end{array}$ & St & MS & $\begin{array}{l}\mathrm{Kn}, 2,4- \\
\mathrm{D}\end{array}$ & Indirect & $\begin{array}{l}2 \mathrm{mg} / 12,4-\mathrm{D}+ \\
0.2 \mathrm{mg} / 1 \mathrm{Kn}\end{array}$ & 5 & $\begin{array}{l}\text { Hasan et al., } \\
(2008)\end{array}$ \\
\hline
\end{tabular}

Abbreviations: CN- Cotyledonary node, N- Nodal, St- Shoot tip, L- Leaflet, C- Cotyledon, P- Petiole, RRoot, A- Anther, S- Stem, H- Hypocotyl

Table 1. In vitro multiplication of different Cassia species 

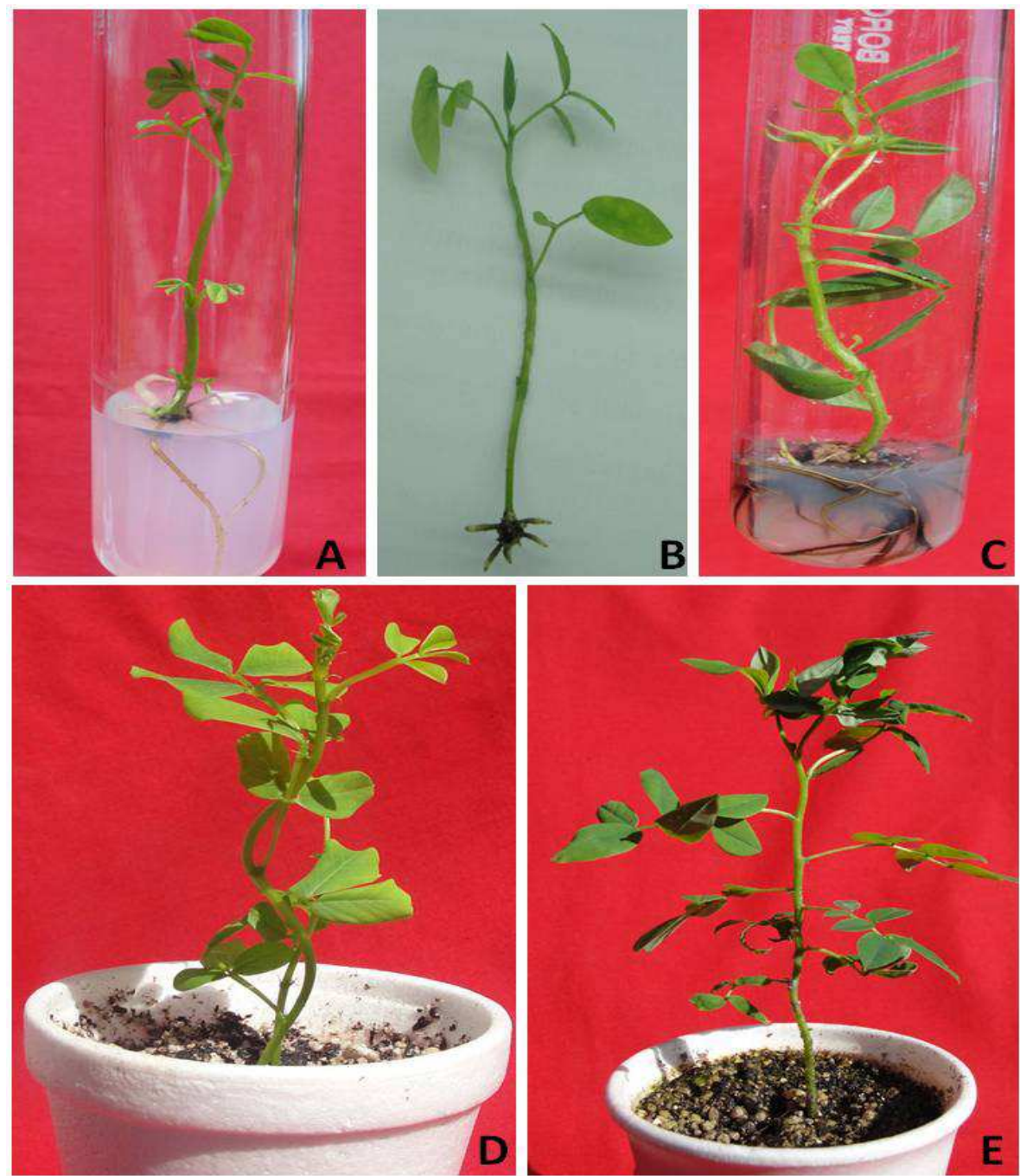

Fig. 2. (A-E) A In vitro rooting of C. alata B\&C. Ex vitro and In vitro rooting in C. occidentalis D\&E. Acclimatized plants of C. alata and C. occidentalis.

\section{Conservation strategies used for the propagation}

Due to growing demand, the availability of medicinal plants to the pharmaceutical companies is not enough to manufacture herbal medicines. There is need to conserve the economically important plants. Tissue culture techniques have been used as tools for germplasm conservation of rare or threatened as well as medicinal plants (Zornig, 1996).

The utilization of in vitro techniques for germplasm conservation is of great interest in plant species (Costa Nunes et al., 2003). The in vitro conservation can be for medium and long 
periods. The conservation for a medium period is done by decreasing the growth of cultures. The long period conservation is done by cryopreservation techniques (Engelmann, 1998).

The establishment of in vitro germplasm banks in developing countries has great importance, but these techniques must be associated with other plant genetic resources conservation practices (Engelmann, 1997). The in vitro conservation techniques allow material exchanges among germplasm banks and the germplasm keeps its sanitary conditions and viability during the transport (Ashmore, 1998). The powerful techniques of plant cell and tissue culture, recombinant DNA and bioprocessing technologies have offered mankind a great opportunity to exploit the medicinal plants under in vitro conditions.

\section{Conclusion and future prospects}

The biotechnological strategies have opened up new vistas in all aspects of plant germplasm characterization, acquisition, conservation, exchange and genetic resource management. Future prospects are highly encouraging in terms of the development and application of new techniques and protocols within the context of germplasm conservation. It is useful for multiplying the species which are difficult to regenerate by conventional methods and save them from extinction. Further, the technology delivery with effective dissemination channels has to play a major role in the commercial production of micropropagated plants, it surely needs to be revived and utilized in a broader spectrum rather than confined to publications. For instance, adoption of tissue culture technology will have to facilitate the use of genetically engineered plants as soon as they become available in near future. Furthermore, technology has always to be understood in a dynamic way. Recent developments in transgenic plants can have multidirectional benefits. The benefits range from manipulating generation time, plant protection, wood quality, production of compounds of pharmaceutical value and improvements to polluted soil.

\section{Acknowledgement}

Authors are grateful to the University Grants Commission, Govt of India, New Delhi for providing research support under UGC- SAP (2009) program. The award of a Research Associateship to I. S. by the Council of Scientific and Industrial Research (CSIR), is gratefully acknowledged.

\section{References}

Abo KA, Adediwura AA, Ibikunle AJ (1998) 1st International Workshop on Herbal Medicinal Products, University of Ibadan, Ibadan, Nigeria.pp. 22 - 24.

Adjanahoun E, Ahyi MRA, Ake-Assi L, Elewude JA, Fadoju SO, Gbile ZO, Goudole E, Johnson CLA, Keita A, Morakinyo O, Ojewole JAO, Olatunji AO, Sofowora EA (1991). Contribution to ethnobotanical floristic studies in Western Nig. Pub. Organization of African Unity: Lagos, Nigeria p.420.

Agrawal V, Sardar PR (2003) In vitro organogenesis and histomorphological investigation in senna (Cassia angustifolia)- a medicinally valuable shrub.Physiol Mol Biol Plants 9:131-140.

Agrawal V, Sardar PR (2006) In vitro propagation of Cassia angustifolia (Vahl) through leaflet and cotylerdon derived calli. Biol Plant 1:118-122. 
Agrawal V, Sardar PR (2007) In vitro regeneration through somatic embryogenesis and organogenesis using cotyledons of Cassia angustifolia (Vahl). In Vitro Cell Dev Biol Plants 43: 585-592.

Ahmad N, Anis M (2007) Rapid clonal multiplication of a woody tree, Vitex negundo L. through axillary shoots proliferation. Agroforestry Syst 7:195-200.

Ahmad Z, Ghafoor A (2002) Resource Base and Conservation Strategies of MAPs in Pakistan. In Sharing Local and National Experience in Conservation of Medicinal and Aromatic Plants in South Asia. Edited by: Bhattarai N. and Karki M. HMGN, IDRC and MAPPA. pp: 105-109.

Akerele O (1992) WHO guidelines for the assessment of herbal medicine . Fitoterapia 62:99110

Alam MM, Siddique MB, Hussain W (1990) Treatment of diabetes through herbal drugs in rural India. Fitoterapia 61:240-242.

Anonymous (1992) The Wealth of India: A Dictionary of Indian Raw Materials and Industrial Products (Vol III). CSIR New Delhi, 366-367

Anonymous (1992) The wealth of India: a dictionary of Indian raw materials and industrials products, vol 3.CSIR, New Delhi 354-363.

Anonymous (1998), The Wealth of India (1998) A dictionary of Indian raw material and industrial products. Council of Scientific and Industrial Research New Delhi, pp 350.

Arya V,Yadav S, Kumar S, Yadav JP (2010) Antimicrobial activity of Cassia occidentalis L (leaf) against various human pathogenic microbes. Life Sci Med Res 1-11.

Ashmore SE (1998) The status of in vitro conservation of tropical and subtropical species. Proceedings of the Internatonal Symposium on Biotechnology Tropical \& Subtropical Species. Acta Hort 461:477-483.

Asolkar LV, Kakkar KK, Chakre OJ (1992) Second supplement to glossary of India medicinal plant with active principles. In: Publication and Information Directorate, New Delhi. CSIR 1:177.

Bhakta T, Mukherjee PK, Mukherjee K, Banerjee S, Mandal SC, Maity TK, Pal M, Saha BP (1999) Evaluation of hepatoprotective activity of Cassia fistula leaf extract. J Ethnopharm 66: 277-282.

Bilal A, Khan NA, Ghufran A, Inamuddin (2005) Pharmacological investigation of Cassia sophera Linn var Pupurea Roxb. Med J Islamic World Ac Sci 15:105-109.

Biswas K,Ghose AB (1973) In Bharatia Banawasasadhi, Calcutta University, Advertisement of learning, Calcutta 2:336.

Bodding PO (1983) Santhal medicine, Laxmi Janardhan Press, Calcutta. 21.

Canter PH, Thomas H, Ernst E (2005) Bringing medicinal plants into cultivation: opportunities and challenges for biotechnology. Trends Biotechnol 23:180-185.

Chopra RN, Nayer SL, Chopra IC (1956) Glossary of India medicinal plants. CSIR, New Delhi 54.

Constabel F (1990) Medicinal Plant biotechnology Planta Med. 56: 421-425.

Costa Nunes EC, Benson EE, Oltramari AC, Araujo PS, Moser JR, Viana AM (2003) In vitro conservation of Cedrella fissilis Vellozo (Meliacea), a native tree of the Brazilian Atlantic Forest. Biodiversity and Conservation 12:837-848.

Crockett Co, Guede-Guina F, Pugh D, Vangah-Manda M, Robinson TJ, Olubadewo JO, Ochillo RF (1992) Cassia alata and the preclinical search for therapeutic agents for the treatment of opportunistic infections in AIDS patients. Cell Mol Biol 38: 799802. 
Cunningham AB (1993) African medicinal plants: setting priorities at the interface between conservation and primary health care. People and plant initiative working paper1, Nairobi: UNESCO.

Damodaran S, Venkataraman S (1994) A study on the therapeutic efficacy of Cassia alata, Linn. leaf extract against Pityriasis versicolor. J. Ethnopharmacol 42: 19-23.

Dhar DN, Qasba GN (1984) Screening of some plant extract for antifunlal activity against venturia inaequalis. Sci Cult 50: 209.

Doughari JG, El-mahmood AM, Tyoyina I (2008) Antimicrobial activity of leaf extracts of Senna obtusifolia L. J Pharm Pharmacol. 2: 7-13.

Ekanayak DT (1980) Plant use in the treatment of skeletal fracture in the indigenous system of medicine in Srilanka. The Srilanka Forester 14: 145-152.

Elujoba AA, Abere AT, Adelusi SA (1999) Laxative activities of Cassia pods sourced from Nigeria. Nig J Nat Prod Med. 3: 51-53.

Engelmann F (1997) Present development and use of in vitro culture techniques for the conservation of plant genetic resources. Acta Hort 447: 471-475.

Engelmann F (1998) In vitro germplasm conservation. Acta Hort 461: 41-47.

Englemann F (2011) Use of biotechnologies for conservation of plant biodiversity, In Vitro Cell Dev Biol Plant 47: 5-16.

Esimone CO, Nworu CS, Ekong US, Okereke B (2008) Evaluation of the antiseptic properties of Cassia alata-based herbal soap, The Intern J Alternat Med 6: 23-32.

Esposito AM, Diaz A, De- Gracia I, De- Tello R, Gupta MP (1991) Evaluation of traditional medicine: effects of Cajanus cajan L and Cassia fistula L on carbohydrates metabolism in mice Rev Med Panama 16: 39-45.

Faisal M, Ahmad N, Anis M (2005) Shoot multiplication in Rauvolfia tetraphylla using thidiazuron. Plant Cell Tiss Org Cult 80:187-190.

Faisal M, Anis M (2003) Rapid mass propagation of Tylophora indica Merrill via leaf callus culture. Plant Cell Tiss Org Cult 75: 125-129.

Faisal M, Siddique I, Anis M (2006) In vitro rapid regeneration of plantlets from nodal explants of Mucuna pruriens- a valuable medicinal plant. Ann Applied Biol 148: 1-6.

FettNeto AG, Fett J P, Aquila MEA, Ferreira AG (2000) In vitro propagation of Senna alata. Planta Medica 66:195-196.

Gadgil M, Rao PRS (1998) Nurturing Biodiversity: An Indian Agenda. Center for Environ.Edu., Ahamdabad, India.

Gharyal PK, Maheshwari SC (1990) Differentiation in explants from mature leguminous trees. Plant Cell Rep 8: 550-553.

Gharyal PK, Rashid A, Maheshwari SC (1983) Androgenic response from cultured anthers of a Leguminous Tree, Cassia siamea Lam. Protoplasma 118: 91-93.

Gupta M, Mazumder UK, Rath N, Mukhopadhay DK (2000) Antitumour activity of methanolic extract of Cassia fistula L. seed against Ehrlich ascites carcinoma. J Ethnopharm 72: 151-156.

Gupta RK (2010) Medicinal and Aromatic plants, CBS publishers and distributors, Ist edition 116-117.

Gupta UC, Jain GC (2009) Study on hypolipidemic activity of Cassia fistula legume in rats. Asian J Exp. Sci. 23:241-248.

Hasan MF, Das R, Rahman MS, Rashid MH, Hossain MS, Rahman M (2008) Callus induction and plant regeneration from shoot tips of Chakunda (Cassia obtusifolia L). Int J Sustain Crop Prod. 3: 6-10.

Husain MK, Anis M, Shahzad A (2007) In vitro propagation of Indian Kino (Pterocarpus marsupium Roxb.) using thidiazuron. In Vitro Cell Dev Biol Plants 43: 59-64. 
Hutchinson J, Dalziel JM (1958) Flora of West Tropical Africa, Second Edition, Vol-1, part 2,Crown Agents for oversea Governments and Administrations, London, 450-455.

Ilavarasan R, Mallika M, Venkataraman S (2005) Anti-inflammatory and antioxidant activities of Cassia fistula Linn barks Extracts. Afr J Trad Comp Alter Med 2: 70-85.

Jafri MA, Subhani MJ, Javed K, Singh S (1999) Hepatoprotective activity of leaves of Cassia occidentalis against paracetamol and ethyl alcohol intoxification in rats. J Ethnopharmacol 66: 355-61.

Jafri, S.M.H. (1966) The Book Corporation, Karachi. p. 156.

Jain SC, Sharma RA, Jain R, Mittal C (1998) Antimicrobial screening of Cassia occidentalis L in vivo and in vitro. Phytotherapy Res 12: 200-204.

Joshi SG (2000) Medicinal plants Oxford \& IBH Publishing Co. pvt Ltd. New Delhi, India 122-123.

Kashiwada Y, Toshika K, Chen R, Nonaka G, Nishioka I (1990) Tannin and related compounds. XCIII. Occurrence of enantiomeric proanthocyanidins in the leguminosea plant, Cassia fistula L; Cassia javanica L, Chem Pharm Bull 38: 888- 893.

Khan MR, Kihira M, Omoloso AD (2001) Antimicrobial activity of Cassia alata, Fitoterapia. 75, 561-564.

Kiritikar KR, Basu BD (1975) Indian medicinal plants, Vo.l III. Reprint Ed., LN Basu Allahabad, 856.

Kirtikar KR, Basu BA (1991) Indian medicinal plants. Vol. II. 2nd edition, periodical experts book agency, New Delhi.277-282.

Kirtikar KR, Basu BD (1935) page 854-879, Vol.1I, published by L.M. Basu.

Knoll KA, Short KC, Curtis IS, Power JB, Davey MR (1997) Shoot regeneration from cultured root explants of spinach (Spenacia oleracea L): a system for Agrobacterium transformation. Plant Cell Rep 17:96-101.

Krithikar KR, Basu BD (1999) Cassia occidentalis Indian Medicinal Plants II edition. p. 860.

Kunwar RM, Nepal BK, Kshhetri HB, Rai SK, Bussmann RW (2006) Ethnomedicine in Himalaya: a case study from Dolpa, Humla, Jumla and Mustang districts of Nepal. J. Ethnobiol Ethnomedicine 2:27.

Kuo YH, Lee PH, Wein YS (2002) Four new compounds from the seeds of Cassia fistula. J Nat Prod 65: 1165-1167.

Little CHA, Savidge RA (1987) The role of plant growth regulators in forest tree cambial growth. Plant Growth Regul 6:137-169.

Liu A, Xu L, Zou Z, Yang S (2009) Studies on chemical constituents from leaves of Cassia alata. Zhongguo Zhong Yao Za Zhi. 34, 861-863.

Luximon- Ramma A, Bahorun T, Soobrattee MA, Aruoma OI (2002) Antioxidant activities of phenolic , proanthocyanidins and flavonoid components in extracts of Cassia fistula. J Agric Food Chem 50:5042-5047.

Mazumdar UK, Gupta M, Rath N (1998) CNS activities of Cassia fistula in mice. Phytotherapy Res 12: 520-522.

Murch SJ, KrishnaRaj S, Saxen PK (2000) Phyto-pharmaceuticals, mass production, standardization and conservation. Herbal Med 4: 39-43.

Nadkarni KM (1954) page 284, 285, 290, 291. V.M. Puranik, G.R. Bhatkal. Publishers, Bombay.

Nalawade SM, Tsay HS (2004) In vitro propagation of some important chinese medicinal plants and their sustainable usage, In Vitro Cell Dev Biol Plants 40: 143-154.

Olabiyi TI, Oyedunmade EEA, Idikunle GJ, Ojo OA, Adesiva GO, Adelasoye KA, Ogunniran TA (2008) Chemical composition and Bio-Nematicidal potential of some 
weed extracts on Meliodogyne incognita under laboratory conditions. Plant Sci Res 1:30-35.

Palanichamy S, Nagarajan S (1990) Analgesic activity of Cassia alata leaf extract and kaempferol 3-Osophoroside. J. Ethnopharmacol 29: 73-78.

Palanichamy S, Nagarajan S, Devasagayam M (1988) Effect of Cassia alata leaf extract on hyperglycemic rats, J. Ethnopharmacol 22: 81-90.

Parveen S, Shahzad A (2010) TDZ-induced high frequency shoot regeneration in Cassia sophera Linn. Via cotyledonary node explants.Physiol Mol Biol Plants 16: 201-206.

Parveen S, Shahzad A (2011) A micropropagation protocol for Cassia angustifolia Vahl. from root explants. Acta Physiol Plant 33: 789-796.

Parveen S, Shahzad A, Saema S (2010) In vitro plant regeneration system for Cassia siamea Lam., a leguminous tree of economic importance. Agroforest Syst 80: 109-116.

Patel D, Karbhari D, Gulati D, Gokhale D (1965) Antipyretic and analgesic activities of Aconatum spicatum and Cassia fistula. Pharm Biol 157: 22-27.

Patel RP, Patel KC (1956) Antibacterial activity of Cassia fistula. Indian J Pharm 18: 107-110.

Pauly G, Danoux L, Contet-Audonneau JL (2002) Method for analysing the ageing of the skin by inducing apoptosis in cell cultures and screening the effects of cosmetic substances. PCT Int. Appl. 8pp, Coden:PIXXXD2WO 0221127 A2 20020314.

Perumal R, Samy S, Igganacimuthu S, Sen A (1998) Screening of 34 medicinal plants antibacterial properties. J Ethnopharm 62: 173-182.

Pulliah T (2002) Medicinal plants in India. Regency Publ New Delhi India. 137-139.

Purohit SS, Vyas SP (2005) Medicinal plant cultivation- A Scientific Approach. Shyam printing press, Jobhpur, India. p. 348-349.

Ramakrishna R, Indra G (1997) A note on the antifungal activity of some indigenous plants. Indian J Anim Sci 47: 226-228.

Rout GR, Samantary S, Das P (2000) In vitro manipulation and propagation of medicinal plants. Biotechnol Adv 18: 91-120.

Saganuwan AS, Gulumbe ML (2006) Evaluation of in vitro antimicrobial activities and phytochemical constituents of Cassia occidentalis. Animal Research International 3: 566-569.

Sarasan V, Cripps R, Ramsay MM, Atherton C, McMichen M, Prendergast G, Rowntree JK (2006) Conservation in vitro of threatened plants-progress in the past decade. In Vitro Cell Dev Plants 42: 206-214.

Sastry BS, Sreelatha T, Suresh Babu K, Madhusudhana Rao J (2003) Phytochemical investigation of Cassia siamea Lam. National seminar on biodiversity conservation and commercial exploitation of medicinal plants, Department of Botany. Osmania University, Hyderabad. 39-40.

Satyavati GV, Sharma M (1989) In: medicinal plants in India. ICMR New Delhi.

Sharma N. Trikha P, Athar M, Raisuddin S (2000) In vitro inhibition of carcinogen induced mutagenicity by Cassia occidentalis and Emblica officinalis. Drug and Chemical Toxicol. 23: 477- 84

Shrestha PM, Dhillion SS (2003) Medicinal Plant Diversity and Use in the Highlands of Dolakha District, Nepal. J Ethnopharmacol 86: 81-96.

Siddhuraju P, Mohan PS, Becker K (2002) Studies on the antioxidant activity of Indian Laburnum (Cassia fistula L.); a preliminary assessment of crude extracts from stem bark, leaves, flowers and fruit pulp. J Agric Food Chem 79: 61-67

Siddique I, Anis M (2007a) High frequency multiple shoot regeneration and plantlet formation in Cassia angustifolia (Vahl) using thidiazuron. Medicinal and Aromatic Plant Sci Biotech 1:282-284. 
Siddique I, Anis M (2007b) In vitro shoot multiplication and plant regeneration from nodal explants of Cassia angustifolia (Vahl): a medicinal plant. Acta Physiol Plant 29: 233238.

Siddique I, Anis M (2009) Direct plant regeneration from nodal explants of Balanites aegyptiaca L.(Del) ; a valuable medicinal tree. New Forests. 37: 53-62.

Siddique I, Anis M, Aref IM (2010) In vitro adventitious shoot regeneration via indirect organogenesis from petiole explants of Cassia angustifolia Vahl. a potential medicinal plant. Appl Biochem Biotechnol 162: 2067-2074.

Silva CR, Monterio MR, Rocha HM, Ribeiro AF, Caldeira-de- Araujo A, Leitao AC, Bezerra RJAC and Padula AC (2007) Assessment of antimutagenic and genotoxic potential of Senna (Cassia angustifolia Vahl) aqueous extract using in vitro assays. Toxicol. In Vitro 20: 212-218.

Sini KR, Karpakavalli M, Sangeetha PT (2010) Analgesic and Antipyretic activity of Cassia occidentalis Linn. World App Sci J 11: 1216-1219.

Sreelatha VR, Prasad PJN, Karuppusamy S, Pulliah T (2007) Rapid micropropagation of Cassia siamea .Plant Cell Biotech Mole Biol 8:173-178.

Srivastava J, Lambert J, Vietmeyer N (1995) Medicinal plants; an expanding role in development. World Bank technical paper No. 320. Washington DC. World Bank Agriculture and Forestry Systems.

Suwal, P.N. (1993) Medicinal plants of Nepal. 4th Ed., His Majesty's Government of Nepal, P 30-33.

Tona L, Cimanga RK, Mesia K, Musuamba CT, Bruyne T D, Apers S, Hernans N, Miert SV, Pieters L, Totte J Vlietinck AJ (2004) In vitro antiplasmodial activity of extracts and fractions from seven medicinal plants used in the Democratic Rebublic of Congo. J Ethnopharmacol. 93: 27-32.

Tona L, Ngimbi NP, Tsakala M, Mesia K, Cimanga K, Apers S, Bruyne TD, Pieters L, Totte J Vlietinc AJ (1999) Antimicrobial activity of 20 crude extracts from nine African medicinal plants used in Kinshasa Congo. J Ethnopharmacol 68: 193-203.

Tripathi L, Tripathi JN (2003) Role of biotechnology in medicinal plants. Tropical of Pharma Res 2:243-253.

Tsay HS, Gau TG, Chen CC (1989) Rapid clonal propagation of Pinellia ternata by tissue culture. Plant Cell Rep. 8: 450-454

Van OFHL (1976) Some aspects of the pharmacology of anthraquinone drugs. Pharmacology (supl). 14:18-29.

Vieira RF, Skorupa LA (1993) Brazilian medicinal plants gene bank. Acta Hort 330: 51-58.

Wann SR, Johnson MA, Noland TL, Carlson JA (1987) Biochemical differences between embryogenic and nonembryogenic cells of Picea abies (L) Karnst. Plant Cell Rep 6: 39-42.

Yang S, Guo H, Guo D, Zheng J (2006) Studies on chemical constituents of hairy root of Cassia obtusifolia. J Chinese Materia Medica 31: 217-219.

Zornig R K (1996) Micropropagation of bromeliads. Revista da Sociedade Brasileira deBromeliads 3: 3-8. 


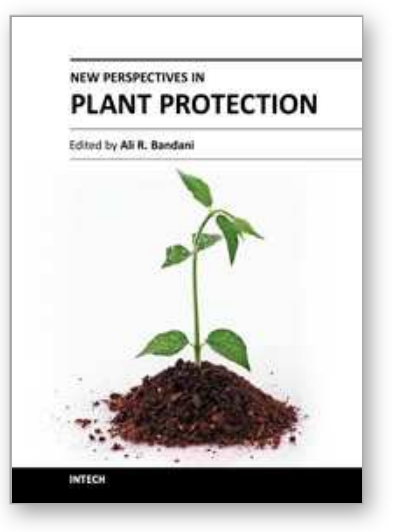

\author{
New Perspectives in Plant Protection \\ Edited by Prof. Ali R. Bandani
}

ISBN 978-953-51-0490-2

Hard cover, 246 pages

Publisher InTech

Published online 11, April, 2012

Published in print edition April, 2012

Crop losses by pests (insects, diseases and weeds) are as old as plant themselves but as agriculture are intensified and cropping patterns including the cultivation of high yielding varieties and hybrids are changing over time the impact of the pests becoming increasingly important. Approximately less than 1000 insect species (roughly 600-800 species), $1500-2000$ plant species, numerous fungal, bacterial and nematode species as well as viruses are considered serious pests in agriculture. If these pests were not properly controlled, crop yields and their quality would drop, considerably. In addition production costs as well as food and fiber prices are increased. The current book is going to put Plant Protection approaches in perspective.

\title{
How to reference
}

In order to correctly reference this scholarly work, feel free to copy and paste the following:

M. Anis, Iram Siddique, Ruphi Naz, M. Rafique Ahmed and Ibrahim M. Aref (2012). Advances in Micropropagation of a Highly Important Cassia species- A Review, New Perspectives in Plant Protection, Prof. Ali R. Bandani (Ed.), ISBN: 978-953-51-0490-2, InTech, Available from:

http://www.intechopen.com/books/new-perspectives-in-plant-protection/advances-in-micropropagation-of-ahighly-important-cassia-species-a-review

\section{INTECH}

open science | open minds

\section{InTech Europe}

University Campus STeP Ri

Slavka Krautzeka 83/A

51000 Rijeka, Croatia

Phone: +385 (51) 770447

Fax: +385 (51) 686166

www.intechopen.com

\section{InTech China}

Unit 405, Office Block, Hotel Equatorial Shanghai

No.65, Yan An Road (West), Shanghai, 200040, China

中国上海市延安西路65号上海国际贵都大饭店办公楼 405 单元

Phone: +86-21-62489820

Fax: +86-21-62489821 
(C) 2012 The Author(s). Licensee IntechOpen. This is an open access article distributed under the terms of the Creative Commons Attribution 3.0 License, which permits unrestricted use, distribution, and reproduction in any medium, provided the original work is properly cited. 